\title{
"We Need Not Be Ashamed of our own Economic Profit Motive": Britain, Latin America, and the Alliance for Progress, 1959-1963'
}

In September 2010, columnist Julian Glover called for Britain to expand its trade with the countries of Latin America. Britain, he wrote, 'needs to trade with those parts of the world that are getting richer.' Latin America was one such place-a place where, in the past, Britain had established powerful financial links but which had, in more recent times, fallen by the wayside. 'Things were once different,' he continued. 'Britain played a noble part in the liberation of the continent from Spanish rule... somehow, in the 20th century, we gave up, diverted by the places we tried to rule. We still are. A fraction of the political and economic effort being applied to Afghanistan or Africa could transform Britain's standing in Latin America.' 'Out across the Atlantic,' he concluded, 'there is a continent that would like to be a friend and partner to Britain, a still-respected alternative to what Latin Americans see as the imposition of North American capitalismo salvaje — wild capitalism, exploitation from the north. ${ }^{1}$

In Whitehall, fifty years earlier, this very debate had been at the centre of British discussions over what, if anything, they should do to bolster their presence in Latin America. ${ }^{2}$ For some officials, especially those in the Treasury, Britain's parlous financial situation and preexisting commitments to the Commonwealth precluded any hopes of expanding into the Americas. For other officials, particularly on the American desk in the Foreign Office, the area was believed to provide a distinct opportunity for expanding Britain's financial and commercial standing without expending too much money.

Yet it was not just financial considerations that shaped British thinking, even though these were of prime importance. Indeed, as these debates unfolded at great length between 1959 and 1963, they were influenced by three inter-related, but nevertheless distinct, factors: the position of the West in the Cold War, calculations over the future of Anglo-American relations, and more basic considerations as to whether it was in London's interests to expend any diplomatic and economic capital in the area. Crucially, it was only when these three positions were aligned-when it benefited the West's position in the Cold War, when it was compatible with shifting patterns in relations between Washington and London, and when it was seen to be a worthwhile investment of British influence - that any real momentum for an expanded British role started to develop. Even then, however, any signs of progress were slow to emerge. For much of the period under consideration, in fact, the arguments against expanding the British role were at least as strong, if not more so, than those for it. It was only in late-1962 and early in the following year that any wider support for a change in policy started to take shape. Moreover, it was only in 1966 - some seven years after the issue had first begun to be discussed seriouslythat the UK sanctioned the expenditure of $£ 4$ million in developmental funding in the area.

It is this interplay between the different factors guiding British thinking that explain why the course of British policy-making toward Latin America was so arduous. Furthermore, this helps to demonstrate why two seemingly vital factors-the desire of US officials to secure British support for their policies, and the position of the West in the Cold War-were not enough to prompt a change in direction despite persistent attempts by the Foreign Office to 
make the case on this basis. ${ }^{3}$ Both of these factors would be important, to be sure, but they would not be enough to dislodge the steadfast stance adopted by the Treasury.

Latin America had been an area of increasing Cold War concern for US policymakers since the culmination of the Cuban Revolution in 1959. ${ }^{4}$ The inauguration of John F. Kennedy in 1961, whose administration believed the US had been too timid in seeking to court the countries of the region in economic terms, led to the announcement of the Alliance for Progress (AFP) — a vast, multi-billion funding project whose intention was to help the countries of the area to become modern economic societies within a decade and, thus, to secure their allegiance to the western cause in the struggle against Soviet communism. ${ }^{5}$ Part of this process, albeit only a minor one, was to try and secure European-and, in particular, British and West Germandiplomatic and financial backing for the Alliance. ${ }^{6}$ This resulted, as we shall see, in ongoing attempts to solicit British support for the Alliance. At times, this was in the form of requests for a diplomatic show of support; at other times, it was a call for an indication that Britain was prepared to commit financially; at still other times, it was part of a wider effort to obtain European backing for the Alliance in an effort to dissipate concerns that it was merely another phase of US predominance in the area. These efforts played a significant part in helping to move British deliberations toward the acceptance of a more engaged policy in the area, yet not to the extent that they would enable the Foreign Office to persuade the Treasury that British policy should be altered. Officials across Whitehall, in fact, were concerned that any move on this front would be deemed unsatisfactory by the Latin Americans and might, in fact, do more harm than good given Britain's shortage of financial resources. Nor did the fact that some of Britain's competitors were more willing to invest in the area-West Germany, chiefly, but also France, Italy and Japan-prompt an immediate shift in policy. Again, such trends were deemed worrisome but they were not enough to initiate a response.

What was needed, therefore, was a third element: a growing belief that it was in Britain's political and financial interest to explore a change in policy toward Latin America more fully. This took much longer to take shape. Within the Foreign Office there had long been a sense that a small investment—as little as $£, 10$ million some officials suggested-could do much to improve Britain's foreign economic outlook. But within the Treasury such a figure, while miniscule compared to the US commitment to the AFP, was deemed to be more than the Exchequer could bear. Eventually, this position began to shift and there was greater confidence in the idea that it would be within London's interests to channel funds to Latin America. As wider enthusiasm for the Empire began to ebb, the British polity more generally was disposed to consider the Western Hemisphere as a promising area for potential expansion. ${ }^{7}$

Presently, there is no existing study of British policy toward the Alliance for Progress in this era. This is not altogether surprising as, even on the US side, the field is only just starting to take shape as scholars confront the enormous difficulty of trying to decipher how they write authoritative works on this era that are both focused enough to deal with the complexity of the AFP and broad enough to get a detailed understanding of the way that it worked in over twenty Latin American countries. ${ }^{8}$ However, examining these events is nonetheless important as it sheds light on the intricacies of Anglo-American relations during the Cold War and, also, highlights the complex factors that fed into British decision-making toward areas in the global south that were not former imperial possessions. While numerous works on US-UK relations during this era 
have focused on whether or not they were positive or negative, the present article suggests that they were less straightforward than existing accounts suggest. ${ }^{9}$ Whereas the focus of existing studies has understandably tended to be on areas or moments of crisis, this article depicts the multi-layered elements that shaped British policy toward an area of prime US influence but in which London's stake was comparatively small. ${ }^{10}$ London did not immediately respond to US requests for assistance; nor did they mobilise when the case was persuasively made that the area now posed a substantive threat to the West's position in the Cold War. Both of these elements made a change in British thinking more likely and featured heavily in evolving discussions, but it was only when a shift was also deemed to accord with London's own interests that a change in attitude became apparent. For British officials, it transpired, investing in Latin America only seemed a viable option once it met political, diplomatic, strategic and, perhaps most importantly, economic goals.

British interests in Latin America, both political and economic, had been in decline since the nineteenth century and the setting out of the Monroe Doctrine in 1823. As US efforts to enforce the doctrine became more vigorous in the late nineteenth century, and notions of it being an area of prevailing US dominance become more commonplace, Britain's once thriving interests there quickly began to dissipate. By 1914, in fact, they were coming under sustained pressure in the face of the inexorable growth of US power in the area and the determined efforts of Latin American nationalists. ${ }^{11}$ A Foreign Office assessment in 1953, by way of indicating how far this shift had gone by the early Cold War, portrayed the area as one where the United States was considered to be the predominant power. ${ }^{12}$ It was a point reaffirmed-none too subtly-by the Dwight D. Eisenhower administration in 1954 during international discussions over a possible US incursion into Guatemala to help remove the government of Jacobo Arbenz. When word reached the White House that British diplomats were undecided about whether or not to support a Guatemalan complaint to the UN about US actions, the administration responded with an imperial comparison whose meaning was patently clear to UK officials. If the British did not back Washington's position, Eisenhower's secretary of state told the ambassador to the UN, then the US 'would feel entirely free without regard to their position in relation to any such matters as any of their colonial problems in Egypt, Cyprus etc. ${ }^{, 13}$

Yet, by 1959, that view was starting to shift and British officials were once again starting to believe that the area might offer opportunities if London was ever minded to try and expand its interests overseas. News that a free trade area (LAFTA) was on the cusp of being created in Latin America prompted serious discussions about the nature of the British position there late in that year. While British financial interests in the area paled in comparison to those in Europe, a Board of Trade report made clear in November, they nevertheless remained significant. 'Last year, the UK sold $f_{1} 153$ million worth of goods to Latin America,' the report noted, 'representing 4.6 per cent of total UK exports and 5.2. per cent of Latin American imports from all sources.' The report recommended that the UK should 'continue to encourage them' and aim to ensure that 'the developments are on sound lines. ${ }^{14}$ Upon completion the report was sent to the Prime Minister, Harold Macmillan, who, after reading it, told his private secretary that 'this was certainly a development which must be watched. ${ }^{15}$ 
In the months that followed, the Treasury sought to determine whether or not they believed LAFTA would prove advantageous. One official, while wary, noted that its creation 'should not have an adverse effect on our trade...indeed it should increase it. ${ }^{16}$ Other officials, though, were more concerned at the prospect of giving their support and running the risk of 'being too soft on the Latin Americans. ${ }^{, 17}$ The Bank of England, meanwhile, was opposed to the idea. The area's entrenched economic problems, a Bank official wrote, would mean that LAFTA's implementation would cause 'UK products...to suffer from discriminatory treatment.' Equally, the move was likely to benefit Britain's competitors as those 'industrial countries with a greater capacity or present propensity to invest in Latin America (e.g. the US, Germany and Japan) may gain at the expense of the UK.,18

Throughout these discussions it was clear that it was largely economic considerations shaping British thinking. But the direction of these deliberations was about to be challenged by the worsening state of US relations with the area. Tensions had been rising in inter-American relations for much of the post-1945 era as Latin American discontent with US intervention and economic policies became more entrenched. By the end of the 1950s, though, these tensions had erupted with greater force as evidenced by the protests that greeted vice president Richard Nixon on a tour of the region in 1958 and, early the next year, the emergence of Fidel Castro's government in Cuba espousing a powerful anti-American line in hemispheric rhetoric. ${ }^{19}$ These events, unsurprisingly, began to affect British appraisals of the area. As the Eisenhower administration strove to engineer an improvement in inter-American relations, British observers recognised that these events would also influence their own approach toward the area.

In early 1960, President Eisenhower had conducted a mini-tour of the area in an effort to cultivate closer relations. Following the trip, though, some British officials argued that its initial success could soon wear off. "There is a fairly wide-spread inclination to sum up the result of the tour by saying "so what?" Harold Caccia, the British Ambassador in Washington, reported to London. 'As an exercise in public relations, on the part of the US, it has no doubt been amply justified. But its success carries with it its own dangers. There is a risk of disillusionment if it is not followed by new and striking policies. ${ }^{20}$ Eisenhower's advisors agreed. Accordingly, in July, Eisenhower announced a $\$ 500$ million social progress fund to alleviate chronic poverty in the region. ${ }^{21}$ In the British view, however, such moves would not serve to placate Latin American discontent. ${ }^{22}$ Overall, British observers at a meeting in Bogota to finalise the social progress fund noted, the Latin Americans were 'reasonably satisfied' by the Eisenhower administration's move. But they had also given notice that 'once US presidential elections are over' they would 'hope that "a fund for economic development will be created with the participation also of other capital exporting countries notably in Europe".,23

At the same time, the discussions that had begun over the impact that LAFTA might have had prompted further discussions in London over the viability of the British government seeking to bolster its commercial presence in the area. This was particularly evident in the Foreign Office where, in the first half of 1960, there was a determined attempt to counter the Treasury's negativity over Latin America by issuing a paper on British policy in the area-a move that, in the weeks and months that followed, drew out the differences between Treasury and the Foreign Office, and which set the tone for the larger moves that would take place after 1961. 
Even in the Foreign Office, it is worth noting, there were signs that officials recognised the divergence between what they would like to do in Latin America and what in practice they would be able to do. An initial draft of the Foreign Office report, which emerged in February, had highlighted substantial benefits to the UK in boosting its economic position in Latin America. Washington's declining influence, it noted, 'has left a gap into which the European business-men and investor can step.' The US would continue to be the dominant power in the region, of course, but it was nevertheless believed that many Latin American countries 'would now welcome European investment as opposed to American and even, perhaps, offer it more favourable terms. ${ }^{24}$

Upon reading this, however, several Foreign Office officials noted their dissatisfaction with its recommendations. Its inherent problem, H.A. Hankey wrote, was that 'after making an overwhelming case in favour of some far reaching policy change in order to restore our position in Latin America, the draft really ends with a whimper-suggesting making, what are after all, relatively not very far reaching political recommendations and virtually recommending on the economic side that we should do what is really already being done about up to the limit of what can be done. ${ }^{25}$ A further revision of the report did little to dispel this feeling. Hankey understood perfectly well that the Commonwealth had to come first, he wrote after seeing the new draft, but they were nevertheless determined to make the case that it was 'ever clearer that the actual aid given by e.g. Germany and France, of the kind we do not allow, is relatively small' but that because 'it is presented well it produces a disproportionate effect.' Britain could keep pace with its competitors, Hankey argued, by spending very little; f,-10 million, he later explained, could make a significant difference. ${ }^{26}$

If some officials in the Foreign Office did not believe the paper went far enough, those that read it in the Treasury — and, to a lesser extent, the Board of Trade_-saw it as being wholly unrealistic. Senior Foreign Office officials sought to defend the paper's arguments. The key problem, Frederick Hoyer-Miller wrote to a counterpart in the Treasury, is that Britain is working to court the Latin American nations through high-level Royal and official visits, but was offering far too little in terms of tangible assistance. 'Whenever a question involving credit for, or investment in, Latin America comes up,' he argued, 'we have found ourselves compelled to give these countries what one could only call least favoured nation treatment. ${ }^{27}$ To be sure, the Treasury were not entirely unsympathetic. 'A great deal of what is said in the memorandum,' one official responded, 'is obviously right.' However, it went on, 'it is also saddeningly familiar. I am frankly doubtful whether, from the economic standpoint, there is much that Government could or ought to be doing to alter the situation... it is certainly a pity that more UK firms do not start direct investments in these countries. But their reluctance is understandable given the more favourable (and safer) opportunities elsewhere. ${ }^{28}$

A more formal Treasury-Board of Trade response accordingly sought to temper the Foreign Office's enthusiasm. It was, the report noted, undoubtedly unfortunate that British trade and investments in Latin America had declined so much from previous highs and the Foreign Office, like many British firms and organisations, would like to see this remedied. But, the report went on, the 'extent to which this should be done must be considered not on the basis of our past achievements in the area, but of its potential.' Past successes did not mean that future investment would derive identical benefits. Furthermore, there was no scope for utilising 
government funds to bolster UK-Latin American relations. 'To get a substantial increase in the UK share in the Latin American market,' the report noted, 'would require an increase in the amount of UK investment, public or private, in the continent...in general...our policy and commitments, particularly the priority which we give to the Commonwealth, preclude entirely the granting of any Government aid to Latin America, or any other non-Commonwealth area except in the most exceptional circumstances.' Increased levels of private investment, it conceded, could help to fill this gap; yet the government could do little to encourage this, and private capital would go where investors saw the greatest likelihood of substantial returns. ${ }^{29}$

Unsurprisingly, the Foreign Office responded in kind. In August they began to try and push back against the Treasury's pessimism. Not only was this stance harming Britain's economic interests, they fumed, but it was also undermining the prospect of being able to position the UK as being supportive of the United States 'Our special position with the US,' one official wrote, 'depends largely on the extent to which we can be seen to exercise a useful influence on the common interest all over the world. We simply cannot afford to abdicate our position in such an important part of it as Latin America. ${ }^{30}$ Another memo, sent from a highlevel Foreign Office advisor to a counterpart in the Treasury, adopted a more balanced view. Clearly, he wrote, Britain's global commitments had to be taken into account, and greater levels of economic assistance could not be sent to Latin America if more pressing concernsparticularly in the Commonwealth-had already swallowed up the available funds. Nevertheless, he continued, the point of circulating the Foreign Office paper had been,

to emphasize that as we have fallen behind in Latin America, and as Latin America has acquired an increased political importance and economic significance for the future, a special effort is needed to bring our achievements there on to a par with what we are doing in other parts of the world, whether inside the Commonwealth or out of it... ${ }^{31}$

The Embassy in Washington reaffirmed this stance. 'In brief, attention to Latin America and readiness to co-operate politically as well as to compete commercially with the US in that area,' the Ambassador, Harold Caccia, explained, 'should, in the next period, be a factor more likely to promote closer Anglo-US relations than to become an apple of discord between us. ${ }^{32}$

But the Treasury remained unmoved. As Frank Lee informed Richard Powell, a colleague at the Board of Trade, the arguments being made by the Foreign Office did 'not really challenge the broad thesis which dominated our thinking': 'namely that a specially mounted campaign on behalf of Latin America would involve an unjustifiable diversion of effort and resources from other parts of the world. ${ }^{33}$ Powell, and his colleagues, agreed. A greater level of British involvement would be nice, Powell concurred, but 'the present situation does not justify any change...in such a way as to give Latin America a degree of priority which would cause resources to be diverted from other parts of the world. ${ }^{34}$

Not everyone in these departments, however, was opposed to the Foreign Office position. In late 1960 a more positive view emerged in a report by Frederick Erroll, the Board of Trade Minister, who had toured the area in September. During his tour various officials, particularly in Brazil, lobbied him to pursue a more active policy when it came to encouraging 
British firms to invest in the region. Other non-governmental observers, such as the head of the Bank of London and South America, were also calling for increased British trade links. ${ }^{35}$ Erroll's subsequent report, finalised in December, made a clear call for enlarged levels of British trade with the area. 'Why do we put so much effort into working with, and understanding, the alien economic systems of Russia and China,' Errol wrote, 'when a great continent wants to welcome us, and offers us the liberal atmosphere of democracy, individual liberty, and the free enterprise way of life?' 'It is not too late for Britain to stage a comeback,' he continued, 'but there must be the political will to do so if our export trade is to expand, and if British investment in South America is to grow.' Moreover, the forthcoming change of government in the US-with John Kennedy preparing to replace Eisenhower-might work in Britain's favour. 'The USA will doubtless continue with massive material aid,' Erroll wrote, 'but I am sure more evidence of British interest and support in all spheres would be very much welcomed. ${ }^{36}$

These debates highlight two themes that would be of greater importance in the months and years that followed. First, it was quite clear that British officials-even those opposed to a more sustained effort in Latin America-were broadly in favour of working to try and develop a stronger British financial and trade presence in the region if circumstances allowed (though in the Treasury's view, of course, this would be some way in the future). Second, it was also apparent that there was a link between British views of the area and the course of US policy. The Foreign Office had made more progress in pursuing their arguments when they could point to this being likely to find favour with those in Washington and as being of value to the Western cause in the Cold War. Eisenhower had heartily backed the idea of Macmillan visiting the area, while some advisors believed that the US would welcome European financial assistance in the region. As the US position in the area worsened, in fact, the more likely it was that Britain would play a larger role.

These conclusions, and the capacity of Foreign Office officials to make them persuasively, strengthened hopes that Britain might be able to expand its stake in the area in the years ahead. Shifts in US policy toward the region initiated by the new administration early in 1961, moreover, would give these arguments an added impetus. Kennedy's pledge that his administration would commit large-scale financial assistance to the task of galvanising Latin American development altered the context for British discussions over their own position. Now, the prospect of being seen as supporting the US had an additional bite to it. Furthermore, attempts to solicit European support, while never a central part of the Alliance, were evident and the British would come under growing pressure to back the Washington's position through a more tangible commitment of economic aid - a situation that only increased as the Alliance began to come under fire just a year after it was announced. As these arguments gathered pace, though, the crucial third element to this decision-making process - that the channelling of funds and influence to Latin America be seen as beneficial to the British government-remained unaltered and would continue to forestall any attempts to alter British policy.

Kennedy announced the Alliance in a speech on March 13, 1961, outlining his administration's goals of 'redressing the region's pervasive underdevelopment and inequality and, in the space of only a decade, transforming it into a stable, prosperous area. ${ }^{37}$ Even before this, however, those 
planning the Alliance had recognised that, at some level, it should have an international dimension. One planning report, finalised in the previous winter, recognised that 'the contribution of public capital should come from Western Europe, Canada, and Japan as well as from the US. ${ }^{38}$ A memo containing suggestions for Kennedy's speech, meanwhile, had recommended that 'European nations may help in some small measure. ${ }^{39}$ Later, during discussions for an inter-American meeting to set out the programme's criteria, a further planning memorandum said that the US should 'encourage other free world countries to provide capital and technical assistance. ${ }^{40}$ Furthermore, the new administration recognised that the appearance of European support would help the administration's efforts to get necessary appropriations passed by Congress. This was likely to be much easier, National Security Council staff member Walt Rostow told State Department advisor George Ball, with European-and, in particular, British and West German—commitments of aid. ${ }^{41}$

This shift in US policy posed a number of questions for British officials. Would the UK be more willing to raise its financial presence in the region as a result of the Alliance? Irrespective of that, should British interests be shaped by perceptions of their own needs in the area or by taking the approach closest to that outlined by Washington? Lastly, what could Britain realistically do in the region given its financial constraints? Currying favour through an infusion of aid, as highlighted in earlier discussions, was potentially seen as a way of furthering Britain's economic footprint. A further motivation, however, was the ongoing fall-out from the Cuban Revolution, which had heightened fears of leftist movements gaining political traction and undermining the prevailing system. In the US, similar fears had provided some of the impetus for the Alliance; for the British, it had led, in the first instance, to an attempt to try and exert diplomatic pressure to promote certain reforms that would nullify the appeal of left-wing agendas. Again, British officials found themselves in a multi-faceted situation, whereby their interests were partly based on their own goals and economic hopes, their own fears of leftist radicalism, and shifting views on whether or not to wholeheartedly back the US. ${ }^{42}$

British advisors had continued to debate their position before the AFP's launch. As Harold Caccia reported in late 1960, it was clear that, at some point, the British would need to 'explain our position' on Latin America to the US, but that they should wait until the new administration had assumed power. ${ }^{43}$ Just a few days later, he sent a further missive-recanting some of his previous advice and suggesting that it might be possible for London to substantially improve its position by making a contribution to the Inter-American Development Bank (IADB). Taking this approach, Caccia acknowledged, would place further stresses on Britain's financial position; at the same time, it would provide a 'very concrete expression of our interest in, and desire to help, the economic development of Latin America. ${ }^{44}$

Even the Foreign Office, however, felt unable to back Caccia's proposal. One official wrote on the front of Caccia's report that there was surely a risk that it could 'merely whet Latin American appetites and eventually bring us ill-, rather than good-, will. ${ }^{45}$ Henry Hankey gave this misgiving additional weight shortly afterwards. 'I fear that our contribution of $£ 10$ million spread over three years,' he wrote, 'might be very unfavourably compared' with US contributions of almost a billion dollars. 'It is well known that we do not try to compete with the Americans in the provision of long-term aid for Latin America,' Hankey continued, 'but a disparity of effort so great as this seems one to which we should not go out of our way to draw attention. ${ }^{46}$ The idea 
that an infusion of aid would prompt Latin American goodwill was also challenged. 'I have no doubt that we should get credit from the US for a contribution of $£ 10$ million to the IADB,' another Foreign Office official wrote, 'but I think the effect in Latin America would be virtually nil. $^{.47}$

Ultimately, this led the Foreign Office to reject Caccia's suggestion. 'I am afraid that we are convinced that it is not a starter,' they told him in reply. 'We are all very doubtful whether we should in fact get much mileage out of it. $£ 10$ million... would be a drop in the ocean compared to the American contribution of $\$ 450$ million' and the 'Latin Americans might indeed resent a UK contribution on political grounds (in view of our status as a colonial power). ${ }^{48}$ This reponse starkly exposed the limitations that the British faced in the region. The Foreign Office had been the cheerleaders for an expanded British position in 1960, yet they also recognised that the sort of money that London could actually afford to spend would have only a limited impact. Support for a stronger presence in the region remained evident, therefore, but the likelihood of achieving this remained slight. Just as importantly, it was proving difficult to find an approach that aligned all three of the interests underpinning British policy. What worked in terms of bolstering AngloAmerican relations, the discussions over Caccia's proposal revealed, did not necessarily benefit the position of the West in the Cold War or accord with London's financial self-interest.

By May there was little sign of any shift in this approach, particularly in Parliament. The problem, one MP noted during a debate about where Britain's limited funds should be spent, was in determining which areas had greatest claim. 'One has this perpetual problem-one cannot help it,' the Member of Parliament explained to the Commons, 'of deciding whether South-East Asia is more important than Africa, or whether Africa is more important than Latin America. ${ }^{49}$ Similarly, after a further debate on foreign aid, a question was submitted asking what assistance Britain gave to Latin America and why. The government's response, delivered by a young Ted Heath, was evasive. Britain, he said, made 'substantial contributions to international organisations which provide assistance to Latin America. ${ }^{, 50}$

Wariness about hewing too closely to the American line also militated against any wholehearted commitment to signing-up to support the Alliance. Early appraisals of the Alliance, indeed, were far from enthusiastic. In June a pessimistic appraisal was sent from the Embassy in Washington, in which the author noted his reluctance to 'make any prediction from here on the chances of long term success.' True, he noted, it was encouraging that the US was seeking to do something in Latin America; nevertheless, the 'major tests' were still to come. 'Congress is in an aggressive mood and more determined than ever to prevent American aid from ending up as air conditioned Cadillacs, swimming pools and military support for corrupt oligarchies,' the report explained. 'Much will therefore depend on how far the Latin American governments are prepared to pull their weight...on whether the Americans can avoid damaging their own idealistic programme by tactlessness and clumsiness in execution. ${ }^{51}$

Strong arguments not to expand the British role in the area, therefore, remained evident by the early summer of 1961 and it is clear that finding common ground between the different elements within British policy was proving difficult. At this point, though, the nature of British discussions began to change-and, slowly but surely, the Foreign Office view began to gain far 
more traction in Whitehall as concerns about the Cold War and the desire to side more openly with the United States became more important to British officials.

A number of reasons can be identified in the historical record to explain this change. Firstly, the desire to cultivate closer relations with the United States remained a key part of British policy. As Kennedy's briefing notes for a meeting with Macmillan in Bermuda in late 1961 made clear: 'The Prime Minister's main purpose is to keep you his best friend. ${ }^{, 52}$ Secondly, the Cold War appeared to be entering a more dangerous phase in the early 1960s. Kennedy's relationship with Soviet leader Nikita Khrushchev had got off to an inauspicious start, while the stand-off over Berlin, mounting tensions in Southeast Asia, and ongoing difficulties in Cuba, all pointed to a worsening in east-west relations in $1961 .^{53}$ Finally, Foreign Office officials, as they had with respect to Southeast Asia in the late 1940s, recognised that framing the issue in Cold War terms could help them to gain the support of other departments. If increasing the British role in Latin America was seen to have Cold War implications it would be deemed a matter of greater importance. ${ }^{54}$ Together, these factors led to a shift in the tone of British debates and gave the Foreign Office a greater capacity to drive the discussions.

Evidence of this change came in the autumn of 1961 when recommendations for an expanded British role in the Western Hemisphere emerged with renewed vigour. 'Despite the unfavourable climate for requesting additional overseas funds of any kind from the Treasury,' a Foreign Office report began, 'the case for extending technical assistance to Latin America is a very strong one...if the major part of Latin America is to be kept on the side of the West during the next ten years, these countries will require economic aid and technical assistance on a massive scale.' Consequently, there was a growing need for greater British assistance. 'Both the US Government and our allies in Western Europe have been reaching the conclusion in recent months that a joint US-Western European effort is needed to shoulder the Latin American burden. ${ }^{55}$ The Treasury, of course, remained unmoved. 'Our resources are so stretched,' they responded, 'that we cannot include Latin America in our plans for future assistance.

However, the Foreign Office's argument now seemed more persuasive; in particular, the Cabinet Office responded favourably to calls to create a new high-level committee on Latin America. In a memo specifically designed to court Cabinet Office support, Foreign Office official Frederick Hoyer-Millar painted a bleak picture of Latin America's prospects. 'In the past year or so,' he wrote, 'Latin America has become one of the principal targets of the Sino-Soviet bloc in the Cold War. Unless both the US and the Western European Governments are prepared to make a concerted effort (not exclusively economic in nature), there is a serious danger that much of Latin America may be lost to the west by 1970.' It was now imperative, Hoyer-Millar continued, that Britain back the Alliance. 'Latin America as a whole is likely to confront us in future with a series of politico-economic problems... which seem to merit joint consideration by departments at higher level than has been the custom in the past. ${ }^{, 57}$

Again, the Treasury objected. ${ }^{58}$ Their view was expressed most clearly by its Permanent Secretary, Frank Lee. 'I can see no prospect in the immediate future of our being able to find money for the countries of South America,' he explained in a riposte to the Cabinet Office. 'For this reason I am against setting up any such committee at present. ${ }^{, 59}$ For the first time since 1959, though, the Treasury position did not prevail. In early 1962, Norman Brook, the Secretary of the 
Cabinet Office, wrote to the Foreign Office and informed them that Hoyer-Millar's proposals had 'been generally welcomed' and that the 'arrangements to establish the new Committee will be made as soon as possible. ${ }^{60}$ In explaining the decision to Lee, Brook stressed that he 'did not ignore' Lee's objections and, indeed, recognised that there was 'no immediate prospect' of finding any money. Nevertheless, he continued, 'I am sure that there are other things to think about in relation to Latin America besides aid; and we cannot altogether exclude the possibility that aid priorities may change. ${ }^{61}$ The formation of this new Committee did not mark a major shift in terms of policy, but it did point to the fact that, in Whitehall, British officials were now more persuaded of the Foreign Office's line on Latin America than they had previously been. Prominent backing for the idea, meanwhile, came from the Duke of Edinburgh after he undertook an official visit to the region in spring 1962. British businesses, he told a group of leading industrialists upon his return, could derive great benefit from investing in Latin America if only they could only grasp the opportunities that existed there. ${ }^{62}$

A wider acceptance of Latin America's Cold War importance had seemingly made a difference. A significant challenge, however, remained for those officials advocating greater UK involvement in Latin America: the need to demonstrate that this stance was compatible with US interests and, crucially, that it was seen as being a worthwhile use of British capital.

As the Foreign Office position started to gain further traction, the Alliance for Progress was coming in for increasing criticism in the US and in Latin America. Indeed, the Alliance seemed to be coming under fire from all sides-from Congress, who were wary about signing-off on such large amounts of expenditure, from the Press, who saw little in the way of progress toward meeting the AFP's ambitious goals, from the Latin Americans, who were much less enthusiastic about it than the administration had expected them to be, and from critics within the administration, who believed the project was flawed and who were unimpressed by the credentials of those Kennedy had nominated to run it. ${ }^{63} \mathrm{~A}$ report by the Bureau of the Budget in the summer of 1962 captured the extent of these gloomy appraisals. 'Our observations are not reassuring,' the report explained. 'It appears to us that US policies and programs are in a state of considerable disarray...there is a wide gap between Alliance concepts and practice. ${ }^{64}$

British assessments were little better. At a conference of the Development Assistance Committee (DAC) of the Organization for Economic Cooperation and Development (OECD), a British report noted that, in recent years, the Latin American 'economic position has turned acutely for the worse ${ }^{65}$ and that the 'Alliance for Progress has unquestionably run into stormy seas. ${ }^{66}$ This, coupled with the fact that British observers were fearful that their European competitors were rapidly moving ahead in the region, seemed to point in the direction of supporting a change in British policy. ${ }^{67}$

However, any sense of a clear resolution remained out of reach. And while some progress had indeed been made since the initial discussions in 1959, there was a long way to go before the British government was persuaded that it should expand its presence in the region. At this point, additional impetus for a shift in British thinking began to emerge as a result of direct 
requests from US emissaries for greater British participation in the Alliance and from the growing acceptance among British officials that US policy was in trouble.

Across the spring and summer of 1962, the Foreign Office asked its missions in Latin America to report back on the Alliance's progress. In general, a summary of these reports noted, any overview of the AFP was certain to 'present a fairly gloomy picture.' However, it went on, there were a number of 'extenuating circumstances'- such as the general concept of the Alliance being 'sound', the necessity of US involvement in any major aid programme in the region, and the fact that the AFP, in spite of everything else, had compelled governments across the area 'to pay at least lip service to the concepts of social and economic reform.' Britain, the report noted, 'should not be too quick to condemn the Alliance' as it was 'likely for the foreseeable future to dominate the field of Western aid to Latin America.' London, it concluded, should be 'prepared publicly to support the aims and objectives of the Alliance as well as coordinate our own aid with it so far as we consider this to be practicable. ${ }^{68}$

The key word here was the last one-practicable. No matter how keen the Foreign Office was to extend Britain's role in the region, if the Treasury said there was no money any support would be limited to a verbal endorsement of the Alliance. The desire to back the US position and bolster the West's position in the Cold War, no matter how strong, could not fix economic realities. Pressure from the US, however, was starting to mount and compelled British analysts to think more carefully about what, specifically, they could look to achieve in Latin America. In September, Teodoro Moscoso, Kennedy's choice to run the AFP, met with the British Ambassador in Bolivia and asked him directly whether 'Britain, Germany and France were willing to "join the Alliance".' Britain, the Ambassador reported to the Foreign Office, would be well advised to tread cautiously. Technical assistance, he wrote in a telegram, was more likely to benefit the UK and any tie-in with the Alliance would 'take time to work out' while the 'present scale of our financial assistance to Latin America is so small as to make the question of integrating it into the Alliance appear faintly ludicrous. ${ }^{69}$

Not everyone agreed. An official from the Overseas Development Institute, who had recently toured the region and also spoken with Moscoso, suggested that Anglo-American relations compelled Britain to support the AFP.

The US needs outside help in dealing with the Hemisphere, and will resent the failure of its allies to provide it. In our turn we need American help in the Commonwealth, where the US is in fact the major supplier of aid... Britain might join the Alliance for Progress... it is not an absurd proposition: we are bound to be approached for aid to South America, we might as well be involved in the policy-making. ${ }^{70}$

For the time being, the Foreign Office agreed with the Ambassador in La Paz. The Alliance 'deserves British support', one official wrote, but 'economic considerations do not permit us to give large-scale financial assistance...we should therefore concentrate on technical assistance-a cheap way of reaping considerable benefits. ${ }^{, 71}$

Problems in Washington, though, were increasing the pressure on London. The Kennedy administration's bid for increased aid appropriations, the Embassy reported in September, was being given a rough ride by Congress and 'the best that could be hoped for' was that the Senate 
would force through a less debilitating cut. ${ }^{72}$ Ongoing problems in securing the necessary funds to meet expanding aid commitments, meanwhile, heightened the US view that they were shouldering too much of the burden. George Ball, a State Department official concerned with Europe, informed Kennedy that US balance of payment problems, which had been a cause for growing concern, only existed because 'we are carrying a disproportionately large share of the Free World's burdens. ${ }^{73}$ Indeed, Kennedy was due to make this very point to a meeting of European financial ministers where, one of his advisors instructed him, he should make it clear that 'during the period when they were unable to make any contribution we willingly carried the whole load alone... we do not remind others of this in order to earn their gratitude, but simply to point out that we bore the responsibility when we could, and if others do not join when they can and we can no longer do it all, our common security will be impaired. ${ }^{74}$

The most overt request for European and British participation in the AFP followed shortly afterwards, in December 1962, when Macmillan was visited by New York Senator, Jacob Javits (R-NY). A long-standing proponent of Atlantic partnership, Javits was firmly behind the US mission to foster economic development in Latin America (a mission that now seemed more urgent following the events of the Cuban Missile Crisis in October) ${ }^{75}$ Prior to his arrival in London, Javits had chaired a meeting of the Economic Committee of the NATO Parliamentarians Conference that had recognised the 'need for a greater acceleration of the economic development of Latin America under the Alliance for Progress' and, more importantly, stated the participants' agreement 'that all of the nations of the Atlantic Community should join in the task now undertaken through the Alliance for Progress... ${ }^{76}$

During his meeting with Macmillan, Javits outlined a proposal. Together with the OAS, the OECD, and the IADB, Javits said, there should be a joint US-European funding plan for Latin America. 'The immediate plan,' he explained, 'was that there should be a broad conference in America which Europe would join as givers, not only of money, but also of experience and techniques. There would be participation by European private enterprise and US private enterprise, although the US Government would not participate because they already had the Alliance for Progress.' For the US, this would help to stave off the problems posed by the flight of Latin American private capital that had emerged as a consequence of Washington's insistence on internal economic reforms. For the Europeans, Javits concluded, the advantages were that:

a) this was something which Europe could do for the US and which the US ardently desired; b) it would be a really useful practical exercise for OECD which at the moment was a rather theoretical body; c) it would give Europe a new area in which to interest itself and might help to take the minds of the Europeans off the negotiations between the UK and the EEC. ${ }^{77}$

Responses to the Javits Plan (as British officials came to call it) were relatively favourable: it could help to alleviate Latin American pressure on Europe over the EEC, while it could also provide Britain with a financial way into the region that accorded with American goals of diversifying the AFP. ${ }^{78}$ Conscious of the limits on their financial resources, however, British officials also had to weigh up what kind of commitment they might be agreeing to. 'Plans are afoot for Europe to come to the aid of the ailing Alliance for Progress,' the Financial Times noted in the wake of Javits' visit. 'Senator Jacob K. Javits sketched out a scheme whereby members of 
the OECD would mount something in the nature of the Marshall Plan for Latin America. ${ }^{, 79}$ The debates that took place after the Javits trip were thus symptomatic of those that had been ongoing since 1959: though there was a broad base of support for the idea of extending Britain's role in Latin America, financial concerns and the exact nature of its relationship with the US continued to affect British judgements, and aligning the competing interests guiding British discussions remained frustratingly out of reach.

British officials had been convinced of Latin America's importance to the western cause in the Cold War throughout the discussions that had taken place since 1959. Now, with the Alliance in trouble and US requests for a greater British and European role in the area increasing in frequency, officials in London could also make a convincing argument by the start of 1963 that a change in policy would also benefit Anglo-American relations. The missing piece, however, remained the economic dimension of the problem. Put simply, could Britain afford to adopt a more engaged approach toward the region and would this prove to be of sufficient benefit to make it a worthwhile risk?

It was a concern that continued to shape British discussions in 1963. The Javits Plan, one Foreign Office advisor cautioned, could be the start of a substantial US effort to enlist greater European support for the AFP. And though there were undoubtedly many 'cogent political arguments' in favour of this, the government's lack of capital, plus continuing disagreements between the Foreign Office and the Treasury, made any wholesale embracement of this unlikely. ${ }^{80}$ Other officials, though, were more positive. 'It is clearly in our interest that the Alliance succeeds,' one official countered. 'I wonder, therefore, whether we should change our tactics and ask the Treasury (if not the Cabinet) to agree to our providing, say, $f 10 \mathrm{~m}$ to be spread over two years for the Alliance for Progress. ${ }^{81}$ Unsurprisingly, a note of caution remained in evidence. 'It may be that American Department consider that we should give the Javits proposal a fair wind for the sake of Anglo-US relations,' another Foreign Office official opined, 'but I am inclined to doubt whether we should earn more political kudos in Latin America by channelling a lump sum to the continent via the OAS. ${ }^{, 82}$

Slowly but surely, then, the obstacles to a larger British role were being overcome. The key consideration, and the argument that provided the best lever for encouraging a change in policy, was the desire to align London more closely with Washington in order to boost US-UK relations. A further consideration, though, was that Britain's continued exclusion from the EEC raised the possibility that London might be excluded from any European contribution to the Alliance. It was the first of these arguments, though, which provided the strongest pull for British officials - a fact that had been powerfully reaffirmed during preparations for an AngloAmerican Conference on Latin America to be held at Ditchley Park in early 1963. In response to all of this, the Foreign Office sent a proposal to the Cabinet Office in March 1963 that set out a call for a change in British policy that was much clearer than previous iterations and which made a powerful case for supporting the Alliance and the US.

...The only hope lies in positive action; and the only such action which looks like being effective is the Alliance for Progress. It is becoming increasingly clear that this 
programme involves financial liabilities which are beyond the resources even of the US. Nor is it only a question of financial resources. One of the major obstacles to the success of the Alliance for Progress is its exclusively US origin. If it can be shown that the Alliance is a genuinely multilateral effort and not simply US aid under a new name, its chances of success will be greatly enhanced...The US administration are strongly in favour of greater European cooperation in the development of Latin America, and consider that Europe has in Latin America a position not unlike that occupied by the US in Africa (ie non-colonial past)...It is recommended therefore that:- we should seek an appropriation of, say, $£ 10$ million to be spread over three years, for development aid to Latin America countries as part of a larger European effort to help the Alliance for Progress. ${ }^{83}$

This proposal, far stronger and much more specific than those seen previously, was markedly similar to the final agreement from the aforementioned meeting at Ditchley Park. The final agreement of the Conference was, in effect, an unambiguous statement of US-UK cooperation in Latin America.

The conference unanimously agreed that the future of the Latin American countries and their continuing and developing association with the other countries of the Free World was of the highest importance to the US and the UK, and indeed to other like-minded counties of the West. They felt it was increasingly important that these latter countries should do all in their power to assist the Latin American countries in their plans for social, economic and political development. ${ }^{84}$

But if the Foreign Office now felt able to move forcefully on this issue they were a long way from winning the argument. Agreement had been reached on the issues of the importance of the area to the West and the idea that a change in policy would boost Anglo-American relations. The economic case, however, had not yet been made. Substantial opposition remained within the Treasury to the entire notion of British participation in the Alliance. 'It is doubtful,' one official wrote after reading the Foreign Office memorandum, 'how far we ought to support the Alliance for Progress, as such, with cash.' If the Latin American nations would 'take the steps necessary to pursue the objectives of the Alliance wholeheartedly or to mobilise their own resources at all effectively,' he went on, 'the need for European capital would be much reduced. ${ }^{85}$ Nor did Treasury officials completely accept the Foreign Office line that the position of the West in the Cold War was at stake or that an Anglo-American mutuality of interests necessitated British support. 'I think the Foreign Office sometimes tend to exaggerate the dangers of the continent going communist on the one hand,' a further report argued, 'and to exaggerate the curative powers of an Alliance for Progress on the other...Fundamentally, where Latin America is concerned, whatever developments may take place in other fields, our interests are much more like those of the other European countries than they are like those of the US. ${ }^{, 86}$

The enduring nature of this division between the Treasury and the Foreign Office was exemplified by a clash over the minutes of a meeting of the Cabinet Office's Latin American Committee (LAC) in March 1963. After seeing the draft version of the minutes, the Treasury protested that they gave 'rather more weight to the Foreign Office views which were expressed than to the doubts which, I think it fair to say, the rest of us felt about their suggestion. ${ }^{87} \mathrm{~A}$ 
revised version was subsequently produced that noted that, while British financial support in Latin America was certainly desirable, the "present shortage of resources made this extremely difficult. ${ }^{88}$

By the spring of 1963, then, British deliberations over Latin America had still not managed to reach a consensus for a shift in policy. Support for an increased British financial presence in the region remained strong, but perennial doubts over Britain's financial stability, the extent to which supporting the AFP suited British interests, and the necessity of pursuing a Commonwealth-first approach to foreign aid, continued to block any decisive action. This, as a report in The Observer noted, was symptomatic of a lack of public and political discussion over the role that aid should play in British foreign policy. 'There is no national political debate at all,' the report noted, 'comparable to that which takes place in deciding how much of our resources to devote to defence. ${ }^{89}$

The situation was cogently expressed in a Foreign Office memorandum following the Anglo-American Conference. Britain, it stated, should 'continue its support of the Alliance for Progress and its ideals and purpose... and it should consider what steps it can take to increase the size and effectiveness of that support'; but, it went on, this had to be weighed against wider British interests. At this point, indeed, doubts were again emerging as to whether British participation would benefit the US and the wider West.

Many posts have expressed concern at the degree of identification of British aid with the Alliance for Progress which we propose, since they argue that the small packets of aid and technical assistance that Britain can provide Latin America are not sufficient to dilute the North American origin of the Alliance in Latin American eyes, and that we are therefore pursuing a policy detrimental to British national interests, particularly commercial, in Latin America, without being of any assistance to the Americans... ${ }^{90}$

Yet if practicalities such as these continued to forestall any major change in policy, evidence was increasingly emerging of a growing attitudinal shift among officials in Whitehall. In particular, officials began to believe that the traditional sticking point-that Britain could not afford to invest anything in the region due to pre-existing commitments elsewhere-was no longer as problematic as it had previously been. There were even signs that the fundamental belief the Commonwealth must come first was starting to weaken. 'Some of our aid, and an increasing amount in the last year or so,' Conservative MP Robert Carr noted in a Commons debate in the spring of 1963, 'goes to foreign countries unconnected with the Commonwealth. We are beginning for the first time, for example, to play a small but real part in Latin America. ${ }^{, 91}$ Similarly, there was also a detailed discussion over whether or not Britain should make a contribution to aid programmes in Central America that would not have got off the ground in 1961. Most notable in this respect was the fact that the Bank of England's opposition to this proposal—which previously had been along similar lines to that of the Treasury—was based on practical, rather than financial, objections. ${ }^{92}$

Tellingly, the Treasury was now starting to espy potential economic benefits in the region-not least because of the fact that London's European competitors were increasing their 
stakes there to seemingly good effect. 'The fact that the [European] Community are showing an interest in Latin America,' one Treasury official wrote to another, 'suggests that we, too, ought to be studying the problems involved and generally reviewing our policies towards that part of the world. ${ }^{93}$ The US, meanwhile, also continued to exert significant pressure on its European allies. In July, the US Ambassador to NATO reported on recent efforts to encourage European participation in the Alliance, noting that the possible advantages to the US were that it would 'serve as concrete evidence (a) we really want them (Europeans to) participate fully in AFP, with voice in key decision-making instrumentality, and not just their money; (b) we are serious about need for increasing appropriate types public sector capital flows. ${ }^{94}$

And while these solicitations were not going to result in a wholehearted pledge of assistance, there was now a groundswell of opinion that backed some kind of increased British role as, at long last, the three elements in Whitehall's decision-making began to coalesce. The region's importance to the West had never really been doubted; now, for the first time, a majority of officials believed that Anglo-American relations could also be improved alongside the pursuit of London's own economic objectives. As a Foreign Office memo made clear shortly after Macmillan's replacement by Alec Douglas-Home, Britain should work alongside the US in Latin America but also seek to ensure that its own goals were met.

We must help Latin America not by working jointly with the US but in parallel, in visible but friendly independence...such stablilizing efforts should be aimed primarily at keeping Latin America in the western camp, but we need not be ashamed of our own economic profit motive. We should not expect gratitude, but there is no reason why we should not earn a bit of cash while helping Latin America to advance. $^{95}$

This version of cooperation was expressed to Thomas Mann, Lyndon Johnson's leading Latin American advisor, by the British Ambassador in Washington shortly after Labour leader, Harold Wilson, had defeated Douglas-Home in the 1964 election. 'I said that there had recently been a considerable increase in interest in Latin America in the UK in the political, economic and cultural fields,' the Ambassador later reported to London. 'This was reflected in our decision to extend our aid programmes in the area which, although small in comparison with the US effort, were, we believed, of value. ${ }^{96}$

$* * * *$

By 1964 there was enough convergence between the different elements underpinning British decision-making to make a more proactive stance toward Latin America possible. To be sure, this did not result in a sea-change in British policy; London would continue to advance cautiously and any notable infusions of aid would take time to emerge. Nevertheless, a shift in British thinking was now evident and highlighted the evolving perspectives that policymakers in the UK had of Britain's place in the world. As the Commonwealth's importance began to erode, the opportunities to expand elsewhere became more attractive and, in financial terms, more affordable. This was the crucial point in British deliberations. From 1959 onwards, the area had been of increasing interest to officials in Whitehall and was seen as one where it furthered the position of the West in the Cold War to develop closer relations. As we have seen, however, this 
was not enough to prompt a more expansive British position. No shift could be countenanced, indeed, unless it was seen as being largely compatible with Anglo-American relations and in Britain's economic interests.

Increasingly, US solicitations of British support for the Alliance for Progress after 1961 made it clear that a larger presence would be welcome and would not be seen as a threat to Washington's own interests. This did not initiate an immediate response, but it did make a change in British policy more likely. Moreover, this only increased as time went on: Macmillan had prioritised improving transatlantic ties, while Britain's recurrent financial problemsculminating, in 1964, 1965 and 1966, with requests to Washington for emergency fiscal assistance-ensured that there would never be too much independence in British actions. ${ }^{97}$ If the US wanted a more substantive British role it was certainly something that London would consider.

Still, no change in policy would be possible unless it was believed to be affordable and of benefit to British interests - and it was this issue that was at the heart of the ongoing dispute between the Treasury and the Foreign Office. Here, British officials ran into the perpetual dilemma of whether they prioritised the so-called special relationship with the United States or their own financial and strategic goals. ${ }^{98}$ If necessary, of course, London had demonstrated that it would pursue its own goals even if these were at odds with the US. This had been illustrated in Cuba, where Britain refused to cede to pressure from Washington to cut bus sales to Castro's government despite the hostility of the Johnson administration. ${ }^{99}$ Ideally, though, the British wanted to chart a way forward that allowed them to pursue their own goals in a manner that was amenable to the White House.

Hence, it was only in 1963 that these competing issues were aligned enough to enable a more engaged stance toward the region to take shape, and only in 1964 and the years afterwards that officials in Whitehall began to consider more closely what they might do in the region. The evolving position was summarised by Harold Caccia, in a memo he wrote urging the Cabinet Office not to disband its Latin American Committee.

Whether we like it or not, Latin America is going to claim an increasing share of our attention. Other countries in Western Europe are beginning to realise that the US cannot be left to deal single-handed with the task of preserving Latin America from totalitarianism on the one hand and anarchy on the other. There is a much greater readiness than before to regard this as a common problem and to seek a solution in concert. It is important for our relations not only with Latin America but also with Europe that we should not be left out of this movement...Side by side with this resurgence of European interest, our own effort in Latin America is steadily expanding in terms of technical assistance, development aid, information and culture. ${ }^{100}$

Caccia proved prescient. In 1966, Foreign Secretary Michael Stewart reported on a tour of the region to Wilson's cabinet. 'It was clear that there was much for the United Kingdom to do in order to make up ground that had been lost commercially in Latin America over recent decades,' Stewart told them. ${ }^{101}$ Later, it was reported that Britain had agreed to provide $f_{4} 4$ 
million worth of developmental funding in the region, an agreement that the Embassy in Washington announced 'represents an important demonstration of British support for the Alliance for Progress... [and] offers renewed evidence of Britain's heightened interest in Latin America', while the president of the Board of Trade affirmed in the Commons that, in light of West German and Japanese advances, the issue of increasing trade in the region was at the 'forefront of our minds." 102 Finally, a statement on British policy towards Latin America, prepared by the Foreign Secretary in June 1966, made it clear that the region was now seen to be one of significant importance. If the West had any hopes of modernising the developing world, Latin America was crucial; if Britain had any hopes of exerting any leadership on this fronteven, in some cases, criticising the US — this was also true. He concluded by setting out three principles that should guide UK policy in the years to come:

(a) It is an important British interest that Latin America should remain in the free world and that we should do what we can to help the Latin Americans to achieve self-sustaining growth in freedom as quickly as possible;

(b) It is equally in our interest in the long term to increase our share of the growing Latin American market;

(c) Both these interests require a more active British presence in the political, cultural and, above all, the economic field; greater priority therefore needs to be given both to Latin America in general and in particular to selected countries in the area. ${ }^{103}$

The position set out by Stewart had grown out of the debates that took place between 1959 and 1963 , and demonstrates the enduring nature of this trifurcated framework that had shaped British thinking. It had taken a long time for the different elements informing British policy to be in line with one another; once this happened it took a similarly long time for this to translate into a visible change in policy. It was a process, moreover, which highlights the fact that British policy in this period, particularly toward an area of the world not typically considered as being vital to the UK, was shaped by more than the exigencies of the Cold War or the desire of British officials to forge closer relations with the United States. Both undoubtedly played their part, as we have seen, yet so, too, did the desire among advisors in Whitehall to shape British policy in a way that was cost-effective and, above all, financially beneficial. 
1 Julian Glover, 'South America Could be a Good Friend but we Ignore it,' Guardian, September 52010

2 In the $1^{\text {th }}$ century, of course, Britain had enjoyed long-standing financial, commercial and imperial ties with those nations in the Western Hemisphere. Following the Venezuelan dispute in 1895, however, and the Destroyer for Bases deal in the Caribbean during World War Two, any real influence that the UK had there had continued to ebb away dramatically. See: Victor Bulmer-Thomas (eds), Britain and Latin America: A Changing Relationship (Cambridge, UK: Cambridge University Press, 1989); Rory Miller, Britain and Latin America in the Nineteenth and Twentieth Centuries (London: Longman, 1993); Jason Parker, Brother's Keeper: The United States, Race, and Empire in the British Caribbean, 1937-1962 (New York: Oxford University Press, 2008), 16-67; Spencer Mawby, Ordering Independence: The End of Empire in the Anglophone Caribbean, 1947-69 (Basingstoke: Palgrave, 2012)

${ }^{3}$ The Foreign Office's efforts on this front were not dissimilar to those evident in the 1940s when, along with likeminded officials in Paris and Washington, they had recast the French effort to regain its Southeast Asian colonies as a situation of pressing Cold War concern. See: Mark Atwood Lawrence, Assuming the Burden: Europe and the American Commitment to War in Vietnam (Berkeley, California: University of California Press, 2005), Chs 5-6; Marc Selverstone, Creating the Monolith: The United States, Great Britain, and International Communism, 1945-1950 (Harvard University Press, 2009)

${ }^{4}$ On problems in inter-American relations at the end of the 1950s, Stephen Rabe, Eisenhower: The Foreign Policy of Anticommunism and Latin America (Chapel Hill: University of North Carolina Press, 1988)

${ }^{5}$ On the Alliance for Progress, Stephen Rabe, The Most Dangerous Area in the World: John F. Kennedy Confronts Communist Revolution in Latin America (Chapel Hill: University of North Carolina Press, 1999); William O. Walker, 'Mixing the Sweet with the Sour: Kennedy, Johnson, and Latin America,' in Diane B. Kunz (ed), The Diplomacy of the Crucial Decade: American Foreign Policy During the 1960s (New York: Columbia University Press, 1994); Michael Latham, Modernization as Ideology: American Social Science and "Nation Building" in the Kennedy Era (Chapel Hill: University of North Carolina Press, 2000), Ch. 1-3; idem, 'Ideology, Social Science, and Destiny: Modernization and the Kennedyera Alliance for Progress,' Diplomatic History Volume 22, No. 2 (Spring 1998), 199-229; Jeffrey Taffet, Foreign Aid as Foreign Policy: The Alliance for Progress in Latin America (New York: Routledge, 2007); Thomas Field, 'Ideology as Strategy: Military-led Modernization and the Origins of the Alliance for Progress in Bolivia,' Diplomatic History, Volume 36, No 1 (January 2012), 147-83; Christopher Darnton, 'Asymmetry and Agenda-Setting in US-Latin American Relations: Rethinking the Origins of the Alliance for Progress,' Journal of Cold War Studies, Volume 14, No 4 (Fall 2012), 55-92 
${ }^{6}$ This feature adds to recent debates about the need to 'globalize' studies of modernization. See: David Engerman and Corinna Unger, 'Introduction: Towards a Global History of Modernization,' Diplomatic History, Volume 33, No. 3 (June 2009), 375-7

7 As John Darwin has noted this was part of a transition in British thinking. John Darwin, The Empire Project: The Rise and Fall of the British World-System, 1830-1970 (Cambridge, UK: Cambridge University Press, 2009), 609-12

${ }^{8}$ For some of the most detailed discussion of this problem, Taffet, Foreign Aid as Foreign Policy...; Field, 'Ideology as Strategy'...;

9 On Anglo-American relations in this era, many of which paint a picture of great harmony, John Dumbrell, $A$ Special Relationship: Anglo-American Relations in the Cold War and After (Basingstoke: Palgrave Macmillan, 2001), 42-61; Richie Ovendale, Anglo-American Relations in the Twentieth Century (Basingstoke: Palgrave Macmillan, 1998); Alan Dobson, Anglo-American Relations in the Twentieth Century: Of Friendship, Conflict and the Rise and Decline of the Superpowers (London: Routledge, 1995); Michael Hopkins, Saul Kelly and John Young (eds), The Washington Embassy: British Ambassadors to the United Staets, 1933-1977 (Basingstoke: Palgrave Macmillan, 2009); for a contrasting view, which sees the relationship as being much less cordial, Nigel Ashton, Kennedy, Macmillan, and the Cold War: The Irony of Interdependence (Basingstoke: Palgrave Macmillan, 2002)

${ }^{10}$ For a good example of this sort of study, focusing on India and Pakistan, Paul McGarr, The Cold War in South Asia: Britain, the United States, and the Indian Subcontinent, 1945-1965 (Cambridge, UK: Cambridge University Press, 2013)

${ }^{11}$ Jay Sexton, The Monroe Doctrine: Empire and Nation in Nineteenth Century America (New York: Hill \& Wang, 2011), 62; Alan Knight, 'Britain and Latin America,' in Andrew Porter and William Roger Louis (eds), The Oxford History of the British Empire Volume III: The Nineteenth Century (Oxford, UK: Oxford University Press, 1999)

${ }^{12}$ Memorandum from R.H. Scott in the British Embassy in Washington DC to the Foreign Office, November 13 1953, FRO 371/103131, The National Archives, Kew, London (hereafter TNA)

13 Telephone Conversation between John Foster Dulles and Henry Cabot Lodge, June 24 1954, DDE Diary June 1954 (1), Box 7, DDE Diary Series, Ann Whitman File, Dwight D. Eisenhower Presidential Library, Abilene, Kansas

${ }_{14}$ Board of Trade Report on Proposed Free Trade Area in Latin America, November 1959; Letter from W.P.W Barnes to P. De Zulueta, November 2 1959, PREM 11/3137, TNA

${ }_{15}$ Note from P. De Zulueta to W.P.W Barnes, November 6 1959, PREM 11/3137, TNA

16 Report by J.G. Thompson, April 1 1960, T 312/212, TNA

${ }^{17}$ Memorandum by R.L. Workman to the Board of Trade, April 4 1960; Memorandum by G. Ashford, April 71960 , T 312/212, TNA

${ }^{18}$ Letter from Richard Ewbank at the Bank of England to the Treasury, April 7 1960, T 312/212, TNA; 'Latin America's Limitations as a Market,' The Guardian, January 9 1960, 7

${ }_{19}$ Alan McPherson, Yankee No! Anti-Americanism in US-Latin American Relations (Cambridge, Mass.: Harvard University Press, 2003); Max Paul Friedman, Rethinking Anti-Americanism: The History of an Exceptional Concept in American Foreign Relations (New York: Cambridge University Press, 2012), Ch 4

20 Telegram from Harold Caccia to Foreign Minister Selwyn Lloyd, March 29 1960, FO 371/147734, TNA

${ }^{21}$ Rabe, Eisenhower..., 142; Bevan Sewell, 'A Perfect (Free Market) World? Economics, the Eisenhower Administration, and the Soviet Economic Offensive in Latin America,' Diplomatic History, Volume 32, No 5 (November 2008), 867

${ }^{22}$ See discussion regarding Statement by Raul Prebisch in Bogota, September 8 1960, T 312/212, TNA

${ }^{23}$ Telegram from the UK Embassy in Bogota to the Foreign Office, September 26 1960, T 312/212, TNA 
${ }^{24}$ Economic Steering Committee Report on UK Policy toward Latin America, February 23 1960, FO 371/152126, TNA

${ }^{25}$ Comment by H.A.A. Hankey on Steering Committee Report, March 18 1960, FO 371/152126, TNA

${ }^{26}$ Comments by H.A.A. Hankey and H.N. Brain on Steering Committee Report, April 19 \& 26 1960, FO

$371 / 152126$, TNA

${ }^{27}$ Letter from F. Hoyer-Miller to F. Lee, June 10 1960, T 236/6379, TNA

28 Treasury follow-up to Foreign Office Report on Latin America, June 13 1960; Note by R. Symons, July 4 1960, T 236/6379, TNA

${ }^{29}$ Paper by the Treasury and Board of Trade, July 20 1960, T 236/6379, TNA

${ }^{30}$ Memorandum by H.A.A. Hankey, August 4 1960, FO 371/147691; Telegram from President Eisenhower to Harold Macmillan, June 10 1960, FO 371/147654, TNA

${ }^{31}$ Memorandum from P. Gore-Booth to F. Lee, August 18 1960, FO 371/147691, TNA

32 Telegram from Harold Caccia to F. Hoyer-Miller, July 28 1960, FO 371/147691, TNA

${ }^{33}$ Memorandum from Frank Lee to Richard Powell, August 24 1960, T 236/6379, TNA

34 Memorandum from Richard Powell to Frank Lee, September 16 1960, T 236/6379, TNA

${ }^{35}$ Letter from R.S. Isaacson of the British Embassy in Rio de Janeiro to R. Goldsmith Private Secretary to the Minister of the Board of Trade, September 9 1960, FO 371/147687; Foreign Office Briefing on Brazil for Minister of the Board of Trade, October 1960, FO 371/147688; 'Opening for Europe in Latin America,' The Times, September 20 1960, 6

${ }^{36}$ Report by Frederick Erroll on visit to South America, Minister of the Board of Trade, December 16 1960, FO 371/147689; 'Trade Thrust in Latin America,' The Times, December 16 1960, 18

${ }^{37}$ Hal Brands, Latin America's Cold War (Cambridge, Massachusetts: Harvard University Press, 2010), 45; George Herring, From Colony to Superpower: US Foreign Relations since 1776 (New York: Oxford University Press, 2008), 716-9

38 'Alliance for Progress: A Program of Inter-American Partnership,' developed at the Foreign Policy Clearing House Conference, Cambridge Massachusetts, December 19 1960, Alliance for Progress, Origins of the Reports 1960, Box 1, Papers of Jack Behrman, John F. Kennedy Library, Boston, Massachusetts (hereafter JFKL)

${ }^{39}$ Memorandum from Lincoln Gordon to Richard Goodwin, March 6 1961, Alliance for Progress 1/61-12/61, Box 290a, Papers of President Kennedy: National Security File, JFKL

40 Summary Guidelines Paper on United States Policy Toward Latin America, July 3 1961, Foreign Relations of the United States 1961-1963 Volume XII, (hereafter FRUS, relevant year and volume number) 33-7

41 Telephone Conversation between George Ball and Walt Rostow, March 1 1961, Latin America 11/23/618/16/63; Telephone Conversation between Ball and Walt Rostow, March 8 1961; Telephone Conversation between Ball and Walt Rostow, April 11 1961, Foreign Aid 1961-1963, Box 5, Papers of George Ball, JFKL; Francis Gavin, Gold, Dollars, \& Power: The Politics of International Monetary Relations (Chapel Hill: University of North Carolina Press, 2004), 59-88

${ }^{42}$ Foreign Office Minute to all Latin American posts (except Havana and Ciudad Trujillo), February 2 1961;

Telegram from UK Ambassador in Chile Ivor Pink to Henry Hankey, February 7 1961, FO 371/155773, TNA. For a press response to the Alliance that saw it as a much-needed response to the rise of Communism in the area, 'West Lacks Time in Latin America,' The Scotsman, February 141961

${ }^{43}$ Letter from Harold Caccia to F. Hoyer-Miller, December 28 1960, FO 371/155773, TNA 
${ }^{44}$ Letter from Harold Caccia to F. Hoyer-Miller, January 4 1961, FO 371/155773, TNA

${ }^{45}$ Note on front of Letter from Harold Caccia to F. Hoyer-Miller, January 4 1961, FO 371/155773, TNA

${ }^{46}$ Memorandum by Henry Hankey, January 27 1961, FO 371/155773, TNA

${ }^{47}$ Memorandum by Henry Hankey, January 27 1961; Comment on Hankey report by H.N. Brain, January 301961 , FO 371/155773, TNA

48 Telegram from the Foreign Office to the UK Embassy in Washington D.C., February 3 1961, FO 371/155773, TNA

${ }^{49}$ House of Commons Debate on the Department of Technical Cooperation Bill, April 25 1961, Hansard Volume 639; Jim Tomlinson, 'The Decline of the Empire and the Economic "Decline" of Britain,' Twentieth Century British History Volume 14, No. 3 (2003), 201-221; idem, 'Inventing "Decline”: The Falling Behind of the British Economy in the Post-war Years,' Economic History Review Volume 49 (1996), 731-57

${ }^{50}$ House of Commons Debate, May 31 1961, Hansard, Vol 641; House of Commons Debate, May 17 1961, Hansard, Vol 640

51 Telegram from the UK Embassy in Washington to the Foreign Office, June 5 1961; Foreign Office Brief - Aid to Latin America, July 14 1961FO 371/155765, TNA

52 Memorandum from National Security Advisor McGeorge Bundy to President Kennedy, December 191961 , Conference with Macmillan, President's Trip Bermuda 12/61, Box 235a, Papers of President Kennedy: National Security Files, JFKL; on Macmillan and Kennedy at this point, Alan Dobson, 'The Years of Transition: AngloAmerican Relations, 1961-1967,' Review of International Studies, Volume 16 (1990), 239-58; Dumbrell, A Special Relationship..., 42-61

${ }^{53}$ Freedman, Kennedy's Wars...; Herring, From Colony to Superpower..., 702-11; Campbell Craig \& Fredrik Logevall, America's Cold War: The Politics of Insecurity (Cambridge, Mass.: Belknapp Press of Harvard University Press, 2009), 196-201; David Reynolds, Summits: Six Meetings that Shaped the Twentieth Century (London: Allen Lane, 2007), 151-207; Michael Beschloss, The Crisis Years: Kennedy and Khrushchev (New York: Harper Collins, 1991); William Taubman, Khrushchev: The Man, His Era (New York: Free Press, 2003), 480-507; on British views of the world situation, Memorandum on East-West Relations by Lord Home the Secretary of State for Foreign Affairs, July 19 1961, CAB $129 / 105$, TNA

${ }^{54}$ Lawrence, Assuming the Burden..., Chs 5-6

${ }^{5}$ Memorandum from the Permanent Under-Secretary at the Foreign Office to Sir Andrew Cohen, October 27 1961, FO 371/155765, TNA

56 'Latin America's Demand for Capital,' Report Produced by the Treasury, December 1961; Memo from RMJ Harris to Sir Andrew Cohen, November 16 1961, FO 371/155765, TNA

${ }^{57}$ Memo from Frederick Hoyer-Millar to Norman Brook, November 30 1961, T 312/523, TNA

${ }^{58}$ Report on Hoyer-Millar's Letter by KS Weston, December 11 1961, T 312/523, TNA; Another consideration at this point, though one overblown by the Foreign Office, was a greater Soviet economic role in the region. On Soviet policy towards Latin America, Stephen Clissold (eds), Soviet Relations with Latin America, 1918-1968 (New York: Oxford University Press, 1970); Ilya Prizel, Latin America through Soviet Eyes: The Evolution of Soviet Perceptions during the Brę̧hnev Era, 1964-1982 (Cambridge, UK: Cambridge University Press, 1990)

${ }^{59}$ Memo from Frank Lee to Norman Brook, December 15 1961, T 312/523, TNA

${ }^{60}$ Memo from Norman Brook to Harold Caccia, January 23 1962, T 312/523, TNA

${ }^{61}$ Letter from Norman Brook to Frank Lee, January 23 1962, T 312/523, TNA 
62 'Blunt Facts_-from the Duke,' The Guardian, April 12 1962, 4; J. Halcro-Ferguson, 'Old Friends who Would like to Buy British Still,' The Observer, April 15 1962, 6

${ }^{63}$ On the Alliance and its critics, Latham, Modernization as Ideology..., 100-8; Taffet, Foreign Aid as Foreign Policy..., 39-46

64 'Survey of the Alliance for Progress Program in Brazil, Argentina, Chile and Bolivia (June 16-July 12 1962),'

Report produced by the Bureau of the Budget, August 7 1962, Alliance for Progress 7/62, Box 290a, NSF, Kennedy Papers, JFKL; 'For “Alianza” A Warning,' Life, March 1962;

${ }^{65}$ Report on the Latin American Economy and the Alliance for Progress by the Department of Economic Affairs, presented to the DAC Conference, February 8-9 1962, FO 371/162010, TNA; on the DAC and its role in OECD, 'DAC in Dates: The History of OECD's Development Assistance Committee,' (2006) taken from: http://www.oecd.org/dataoecd/3/38/1896808.pdf Accessed on August 15 2010; on Britain and the DAC, Adrian Hewitt, 'British Aid: Policy and Practice,' Development Policy Review, Volume A11, Issue 2 (October 1978), 51-66

${ }^{66}$ Telegram from David Ormsby-Gore to the Foreign Office, May 4 1962; Note by AD Parsons, May 15 1962, FO 371/162603, TNA

${ }^{67}$ Memorandum by RMB Chevalier (British Embassy in Bonn) to the Foreign Office on West German Government's interest in Latin America, May 19 1962; Note on front of Telegram by AD Parsons, May 221962, FO 371/162013, TNA

${ }^{68}$ Foreign Office Minute by AD Parsons, August 23 1962, FO 371/162606, TNA

${ }^{69}$ Telegram from the UK Embassy in Bolivia to the Foreign Office, September 3 1962, FO 371/162606, TNA

${ }^{70}$ Report on Tour of South America by William Clark (Overseas Development Institute), September 11 1962, OD $9 / 9$, TNA

${ }^{71}$ Telegram from the UK Embassy in Bolivia to the Foreign Office, September 3 1962, FO 371/162606, TNA

72 Telegram from the UK Embassy in Washington to the Foreign Office, September 23 1962, FO 371/162606, TNA; on Congressional cuts to the AFP, Taffet, Foreign Aid as Foreign Policy, 39-43; Felix Belair, 'House Pressing Large Foreign Aid Cut,' New York Times, September 131962

${ }^{73}$ Memorandum from Under Secretary of State George Ball to President Kennedy, July 24 1962, Balance of Payment and Gold General 6/62-3/63, Box 291a, NSF, JFKL; Gavin, Gold, Dollars, \& Power..., 80-9

${ }^{74}$ Memorandum from Special Assistant to the President Carl Kaysen to President Kennedy, September 181962 , Balance of Payment and Gold General 6/62-3/63, Box 291a, NSF, JFKL

${ }^{75}$ Remarks by Senator Jacob Javits on the Senate Floor, December 19 1963, Box 30, Papers of Jacob K. Javits, SUNY Library, Stony Brook, NY; 'Latin America: Cry for Progress,' Time, April 81966

${ }^{76}$ Record of NATO Parliamentarians Conference, Paris, November 16 1962, PREM 11/4580, TNA

${ }^{77}$ Record of Conversation between Prime Minister Macmillan and Senator Javits, December 12 1962, PREM $11 / 4580$, TNA

${ }^{78}$ Telegram from the UK Embassy in Mexico City to the Foreign Office, November 6 1962; Memorandum from RMK Slater (Foreign Office) to the British Ambassador in Mexico, November 21 1962; see also the discussion on the front of Telegram from UK Embassy in Mexico to the Foreign Office, November 7 1962, FO 371/162608, TNA

79 'Plan to Coordinate European Aid for Latin America,' Financial Times, December 131962

${ }^{80}$ Note on Javits-Macmillan Meeting by J Thomas, December 21 1962, FO 371/162010, TNA

${ }^{81}$ Note on Javits-Macmillan Meeting by JRS Guinness, January 1 1963, FO 371/162010; also, Memorandum from FC Mason to WPW Barnes, January 25 1963, OD 9/9, TNA 
82 Note on Javits-Macmillan Meeting by D West, January 3 1962, FO 371/162010, TNA

${ }^{83}$ Memorandum from the Foreign Office to the Cabinet Office, March 8 1963, CAB 21/5577, TNA

${ }^{84}$ Report on the Ditchley Foundation Conference to Harold Caccia, March 28 1963, FO 371/167849, TNA

${ }^{85}$ Memorandum by RL Sharp, March 12 1963, T 312/523, TNA

${ }^{86}$ Memorandum from JG Thompson to RL Sharp, March 12 1963, T 312/523, TNA

${ }^{87}$ Memorandum from RL Sharp to NJ Abercrombie, March 9 1963; Memorandum and Attachment from RL Sharp to NJ Abercrombie, March 9 1963, CAB 21/5577, TNA

${ }^{88}$ Letter and Attached Memorandum from Robin Edmonds to NJ Abercrombie, March 14 1963, CAB 21/5577, TNA

89 Samuel Brittan, 'Another Pennyha'p'orth of Aid?', The Observer, March 31 1963, 9

${ }^{90}$ Foreign Office Minute on Ditchley Park Conference, July 19 1963, FO 371/167849, TNA

${ }^{91}$ House of Commons Debate on Under-Developed Countries, May 10 1963, Hansard Volume 677

${ }^{22}$ Foreign Office minute by AD Parsons, September 5 1963; Meeting of Foreign Office Expenditure Committee, September 3 1963; Letter from Bank of England to Treasury, December 17 1963, FO 371/167748, TNA

${ }^{93}$ Memorandum from JG Owen to RL Sharp, June 11 1963, T 312/523, TNA

94 Telegram from US Ambassador to NATO in Paris to Department of State, July 22 1963, Alliance for Progress 7/8/63-8/16/63, Box WH-2, Schlesinger Papers, JFKL

${ }^{95}$ Memorandum by RL Busk to HL Caccia, May 18 1964, FO 371/173554, TNA

96 Telegram from the British Embassy in the US to the Foreign Office, November 5 1964, FO 371/173554, TNA

${ }^{97}$ Kevin Boyle, 'The Price of Peace: Vietnam, the Pound, and the Crisis of the American Empire,' Diplomatic History, Volume 27, No. 1 (January 2003), 37-72; Dumbrell, A Special Relationship..., 58-65

98 This, moreover, was part of a wider pattern, Matthew Jones, Conflict and Confrontation in South East Asia, 1961-1965: Britain, the United States, and the Creation of Malaysia (Cambridge, UK: Cambridge University Press, 2002), 304; Gavin, Gold, Dollars, \& Power...

${ }^{99}$ Christopher Hull, “'Going to War in Buses”: The Anglo-American Clash over Leyland Sales to Cuba, 1963-1964,' Diplomatic History, Volume 34, No 5 (November 2010), 793-822

100 Memorandum from HL Caccia to Burke Trend, November 15 1963, CAB 21/5354, TNA

${ }^{101}$ Conclusions of Cabinet Meeting, January 201966 CC (66) $2^{\text {nd }}$ meeting, CAB 128/41, TNA

102 'Britain Lends f4M For Latin American Aid,' The Times, April 18 1966; House of Commons Debate on Trade with Latin America, May 19 1966, Hansard Volume 728

103 'British Policy Towards Latin America,' Memorandum by British Foreign Minister Michael Stewart, June 1966, C (66), CAB 129/125, TNA 